\title{
The tonic aspects of human REM sleep during long-term intensive verbal learning
}

\author{
PAUL MEIENBERG \\ Department of Clinical Neurophysiology \\ Max-Planck-Institute of Psychiatry, 8 Munich 40, West Germany
}

\begin{abstract}
The effect of an all-day, 3-week intensive language course in French on the undisturbed sleep of a male subject is being studied in a long-term experiment. The goal of this study is to obtain further information about the relation between learning and memory processes, and the different aspects of sleep. In most of the numerous theories about the memory function of sleep, it is postulated that REM sleep fulfills a memory-promoting function. The tonic aspect of REM sleep was the first sleep variable analyzed in this study. The results are dealt with in this report. With a meaningful learning task, such as learning a foreign language, it is possible to achieve a high degree of learning motivation. Undesirable side effects from emotional disturbances which might compete with the learning and memory processes in their influence on sleep were not present. The subject was able to accustom himself to sleeping under laboratory conditions during 5 adaptation nights. Forty-five consecutive nights-14 preexperimental baseline, 19 experimental, and 12 postexperimental baseline nights-were recorded. In both baseline phases, the subject was able to arrange his days as desired, but was requested not to undertake any physically or mentally strenuous activity. The percentage of REM sleep during the learning phase showed no significant variation from the baseline phases. The only REM sleep parameter which varied significantly was the latency of the third REM sleep phase. It was-in relation to the time of falling asleep-shortened by about $30 \mathrm{~min}$ during the learning phase as opposed to the baseline phases (significant at the $5 \%$ level).
\end{abstract}

Experimental investigations with humans as to the influence of sleep on the retention of verbal learning material have shown that the subjects remember more if they sleep during the period between completion of the learning task and the beginning of the retention test, rather than remaining awake. Jenkins and Dallenbach (1924) were the first to demonstrate, by means of such an experiment, a positive effect of sleep on memory. This memory-promoting effect of sleep has been confirmed in many further experiments (see Lovatt \& Warr, 1968). It has been shown, however, in more recent experiments, that this effect is of a complex nature (e.g., Benson \& Feinberg, 1975; Hockey, Davies, \& Gray, 1972); as was made clear in the 1950s, sleep is not a simple, passive state, but a most complex, active, and rhythmic process (Jouvet, 1963, 1965a; Snyder, 1965).

The discovery of a sleep stage with rapid eye movements (REM) and low-voltage mixed-frequency EEG by Aserinsky and Kleitman (1953) as well as Dement and Kleitman (1957) led to the division of sleep into

This research was supported by Deutsche Forschungsgemeinschaft (Si $213 / 1$ ). The author wishes to express his gratitude to Dr. O. Simon for her advice, to Dr. W. Rassmann for the medical examination of the subject, to Dr. E. Hansert for his assistance in carrying out the statistical analysis, and to Mrs. I. Parik for her technical assistance. The author's address is Department of Clinical Neurophysiology, Max-Planck-Institute for Psychiatry, Kraepelinstrasse 10, 8 Munich 40, West Germany.
REM and non-REM sleep (NREM sleep with stages 1 to 4), which were held to be two fundamentally different states (Jouvet, 1963, 1965a; Snyder, 1965).

Sleep research had reached a stage by mid-1960s which stimulated many sleep researchers to propose various theories as to the memory function of sleep (e.g., Breger, 1967; Dewan, 1968, 1970; Gaardner, 1966; Hernández-Peón, 1966, 1967; Jouvet, 1965b; Meissner, 1966, 1968; Moruzzi, 1966; Newman \& Evans, 1965; Oswald, 1969; Shapiro, 1967). Practically all of them presumed that information processing and consolidation take place during REM sleep, whereby the tonic aspect of REM sleep, i.e., its duration and time of appearance in the course of sleep, was dealt with almost exclusively; the phasic components were given little consideration (for distinction between tonic and phasic components, see: Grosser \& Siegal, 1971; Molinari \& Foulkes, 1969; Moruzzi, 1965).

Assuming that REM sleep does play a role in memory formation, it would be expected that intensive learning processes lead to an increase in duration of REM sleep in the directly following sleep periods, and that by selective REM-sleep deprivation (REMD)-before or after the learning phaseretention would be impaired. In numerous animal experiments, results have been achieved which, although not free of contradictions (see Chernik, 1972; Pearlman \& Becker, 1974b), seem to provide 
some evidence for the contribution of REM sleep to the processes of memory formation (e.g., Fishbein, 1970, 1971; Fishbein, Kastaniotis, \& Chattman, 1974; Hennevin, Leconte, \& Bloch, 1974; Leconte \& Hennevin, 1973; Leconte, Hennevin, \& Bloch, 1973; Linden, Bern, \& Fishbein, 1975; Pearlman \& Becker, 1973, 1974a, 1974b; Smith, Kitahama, Valatx, \& Jouvet, 1974; Stern, 1971; Wolfowitz \& Holdstock, 1971).

The previous experiments with humans have produced no certain evidence that REM sleep is necessary for memory formation. After verbal learning tasks, neither REM-sleep duration nor other REM-sleep parameters was changed during undisturbed sleep. For the experiments cited below, references are made to the number of nights recorded and to the duration and kind of learning with the following abbreviations: adaptation night $=\mathrm{A}$; baseline night $=\mathrm{B}$; experimental night $=\mathrm{E}$; learning $=\mathrm{L}$. Hauri (1968), $1 \mathrm{~A}, 1 \mathrm{E}, \mathrm{L}=6 \mathrm{~h}$ intensive study; Castaldo, Krynicki, and Goldstein (1974), 2 A, 1 B, $2 \mathrm{E}, \mathrm{L}=20 \mathrm{~min}$ learning of 15 trigrams and 15 paired associations; Holdstock and Verschoor (1974), during preparation for examination: $1 \mathrm{~A}$ and $1 \mathrm{E}$; at the time of the examination: $1 \mathrm{~A}$ and $1 \mathrm{E}$; 2 to 3 months after the examination: $1 \mathrm{~A}$ and $1 \mathrm{~B}$; De Koninck, Proulx, Healey, Arsenault, and Prévost (1975), 2 A and 2 B before, 2 A and 2 E during, and $2 \mathrm{~A}$ and $2 \mathrm{~B}$ after an all-day French course over several weeks. After visual-perceptual learning processes, which were brought about by wearing distortion spectacles on the days of the experimental phase, Zimmermann, Stoyva, and Metcalf (1970), as well as Prévost, De Koninck, and Proulx (1975; $2 \mathrm{~A}$ and $2 \mathrm{E} ; 2 \mathrm{~A}$ and $2 \mathrm{~B} ; 2 \mathrm{~A}$ and $2 \mathrm{E}$ ) found an increase in REM-sleep phase and a tendency to a shorter latency for the first REM-sleep phase. On the other hand, during an intraindividual study with three subjects, Allen, Oswald, Lewis, and Tagney (1972; 1 A, 6 B, $6 \mathrm{E}$, and $6 \mathrm{~B})$ could not find any change in REM sleep in the course of a 6-day learning phase, during which a daily learning progress was provable. In no experiment in which subjects were deprived of REM sleep-before or after learningdid verbal memory become worse (Adelman \& Hartmann, 1968; Chernik, 1972; Ekstrand, Sullivan, Parker, \& West, 1971; Empson \& Clarke, 1970; Feldman \& Dement, 1968; Greenberg, Pearlman, Fingar, Kantrowitz, \& Kawliche, 1970; Levy \& Coolidge, 1975; Muzio, Roffwarg, Anders, \& Muzio, 1972).

In summary, it can be said of human experiments that it has been possible so far to prove neither an influence of intensive learning on REM sleep nor a deterioration of memory through REMD. The purpose of the present study was to investigate the influence of intensive, long-duration, verbal learning processes on sleep in long-term experiments, beginning with one subject. In this report, the first sleep variable, REM sleep in its tonic aspect, will be analyzed in detail and the results discussed.

\section{METHOD}

\section{Subject}

In the selection of the subject for this long-term experiment, schooling and occupational background as well as the results of a psychological and medical examination were considered. The selected male subject, an elementary school graduate, was 25 years old and by occupation a construction draftsman. His native language was German. He spoke a very little English but otherwise had no knowledge of foreign languages. Sleep disturbances were not present. From psychological testing, it was established that the subject had no extremes of personality and an aboveaverage intelligence and memory performance. The medical examination, including chemical laboratory tests, revealed no indication of organic illness. Routine and sleep EEGs were normal. The subject's consumption of cigarettes, coffee, and tea was moderate.

\section{Recording Techniques and Sleep Scoring}

The polygraphic sleep recording was done with a 16-channel Mingograph from Siemens-Elema-Schönander, combined with a Beckman Type $R$ Dynograph. It consists of six unipolar EEG derivations (F3, C3, O1 each against $\mathrm{Al}$ and $\mathrm{F} 4, \mathrm{C} 4, \mathrm{O} 2$ each against A2, with time constant of $1 \mathrm{sec}$ and $30 \mathrm{~Hz}$ filter), two monocular EOG derivations (horizontal and vertical with time constant of $10 \mathrm{sec}$ ), EMG derivations from chin and periorbital from outer eye muscles (time constant, $0.015 \mathrm{sec}$ and $700 \mathrm{~Hz}$ filter), EKG, finger photoplethysmogram, respiration, and skin potential reactions.

Sleep was classified in sleep stages according to the convention specified by Rechtschaffen and Kales (Note 1). In the few instances in which REM sleep was interrupted by less than 15 min of NREM sleep, continuous REM sleep was scored (see Globus, 1970; Lewis 1974; Moses, Lubin, Naitoh, \& Johnson, 1972). One period of the ultradian sleep rhythm was defined as one NREM-REM sleep cycle (Feinberg, 1975; Lewis, 1974).

A number of REM sleep parameters were chosen in which changes could be expected during intensive learning according to the hypothesis of memory function of REM sleep. These included the percentage of REM sleep per night, the latency and duration of the REM-sleep phases, and the duration of REM sleep within the individual REM-sleep phases. The Kruskal-Wallis $\mathrm{H}$ test was used for statistical comparison of the preexperimental, experimental, and postexperimental phases.

\section{Procedure}

The learning task consisted of a 3-week intensive course in French at a Berlitz School of Languages. The subject received individual instruction according to the Berlitz Total Immersion ${ }^{\circledR}$ method from Monday through Friday from 0845 to $1830 \mathrm{~h}$. In addition, about $2 \mathrm{~h}$ of exercise daily were involved. On both weekends during the course, the subject studied for about 5 to $6 \mathrm{~h}$ daily. With this "meaningful" learning task, a high degree of learning motivation throughout the course can be achieved. There is no final examination on which further progress of the student is dependent, so that undesirable side effects from anxiety, provoked by the examination, and which may interfere with learning and memory processes in their influence on sleep, are hardly to be expected. Due to the programmed nature of the learning material, it is possible to make quantitative assessments of the amount learned daily.

The subject was able to accustom himself to sleeping under laboratory conditions during 5 adaptation nights, of which the 
last 3 were consecutive 1 week before the beginning of the experiment. Fourteen preexperimental baseline nights, 19 experimental nights, and 12 postexperimental baseline nights were recorded consecutively. The subject appeared in the sleep laboratory each evening at $21.00 \mathrm{~h}$ during the entire experiment, and went to bed at about $23.00 \mathrm{~h}$ ( $\pm 20 \mathrm{~min})$. He was allowed to sleep up to $8 \mathrm{~h}$, but could, if he desired, get up earlier. During the preexperimental and postexperimental baseline phases, the subject could arrange his day as desired, but was not permitted to sleep during the day and was requested to avoid any emotionally disturbing situations.

\section{RESULTS}

The daily learning performance of the subject during the experimental phase is, so far as this can be quantified, given in Table 1. According to the judgment of his teachers, the subject completed the French course with very good success, achieving an active vocabulary of about 1,000 words as well as sentence construction capability in accordance with the basic grammar of the French language. According to the daily interviews and mood questionnaires which were required to be filled out several times daily, the subject did not feel himself to be emotionally burdened at any time. The learning phase was, as expected, felt to be mentally strenuous, which, however, did not impair the uniformly high level of learning motivation. The first night of the learning phase could not be included in the evaluation, since the subject, due to an acute attack of indigestion which occurred in the course of the evening, went to bed very late and slept scarcely $6 \mathrm{~h}$. Instruction on the 2 nd day of the learning phase began at 12:00 noon.

The percentage of REM sleep to total sleep time for individual nights showed no noticeable change in the course of the experiment (see Figure 1). The mean values and standard deviations for various REM-sleep parameters are given in Table 2 for the preexperimental baseline phase, the experimental phase, and the postexperimental baseline phase. The use of the Kruskal-Wallis test for comparison of the three phases was done under the assumption of independence of data within and between the phases. With the exception of the reduced latency of the third REM sleep phase $(p<.05)$, no significant differences were found in any other parameters of the tonic components of the REM sleep between the learning and the two baseline phases (see Table 2).

Two further statistically significant alterations in sleeping behavior under the experimental condition, which have been found during the current analysis of the sleep records, should be mentioned here. First, during the learning phase, the sleep onset latency (time from "lights out" until the first sleep spindle) was longer in comparison to the values obtained during the baseline phases. Further, the duration of sleep stage 4 decreased, whereas no significant changes were found for sleep stage 3 (only a weak
Table 1

Daily Learning Performance During the Experimental Phase

\begin{tabular}{lccccc}
\hline Night Number & $\begin{array}{c}\text { Number } \\
\text { of words } \\
\text { learned }\end{array}$ & $\begin{array}{c}\text { sentence } \\
\text { forma- } \\
\text { tion }\end{array}$ & $\begin{array}{c}\text { key } \\
\text { questions }\end{array}$ & $\begin{array}{c}\text { duration of } \\
\text { self study } \\
\text { (hours) }\end{array}$ \\
\hline first & 15 & 170 & 7 & 12 & - \\
week & 16 & 40 & - & 4 & 2 \\
& 17 & 75 & 4 & 3 & 2 \\
& 18 & 57 & 4 & 2 & 2 \\
first & 19 & 63 & - & 1 & 2 \\
weekend & 21 & - & - & - & 6,5 \\
second & 22 & - & - & - & 7 \\
week & 23 & 40 & - & - & 2 \\
& 24 & 83 & - & - & 2 \\
& 25 & 113 & - & 3 & 2 \\
second & 26 & 33 & - & - & 2 \\
weekend & 27 & - & - & - & 2 \\
third & 29 & - & - & - & 5 \\
week & 30 & 20 & - & 2 & 2 \\
& 31 & 51 & 1 & 2 & 2 \\
& 32 & 76 & - & - & 2 \\
& 33 & 27 & - & - & 2 \\
\hline
\end{tabular}

Note-Individual instruction from 8.45 to $18.30 \mathrm{~h}$ daily on weekdays, with the exception of the 16th test day: instruction from 12.00 to $18.30 \mathrm{~h}$.

tendency to increase exists) or during slow-wave sleep (sleep stages 3 and 4 together).

\section{DISCUSSION}

The search for the sleep variable which is responsible for the memory-promoting effect of sleep has remained unsuccessful with human beings up to the present. In all human experiments which investigated the effect of verbal learning on sleep, no changes have been shown in the tonic component of REM sleep or in any other sleep stage during the learning phase.

For the planning of the present experiment, it was assumed that in these experiments (see statements as to experimental design in the introduction) the required test conditions to prove the influence of learning on sleep had either not, or only partially, been fulfilled, with the single exception of the investigation of Allen, Oswald, Lewis, and Tagney (1972). A number of investigations have indicated that the adaptation to sleeping in the laboratory may last over several nights (Agnew, Webb, \& Williams, 1966; Berger, 1969; Hartmann, 1968; Rechtschaffen \& Verdone, 1964; Schmidt \& Kaelbling, 1971). It has also been shown that a larger variability in the sleep parameters from night to night is to be expected (Chernik, Schless, \& Mendels, 1975; Clausen, Sersen, \& Lidsky, 1974; Moses, Lubin, Naitoh, \& Johnson, 1972; Webb \& Agnew, 1969).

The present study was designed as a long-term experiment. In this way, the subject is able to become accustomed to sleeping in the laboratory and a larger number of nights can be recorded for each experi- 
$\%$ REM sleep

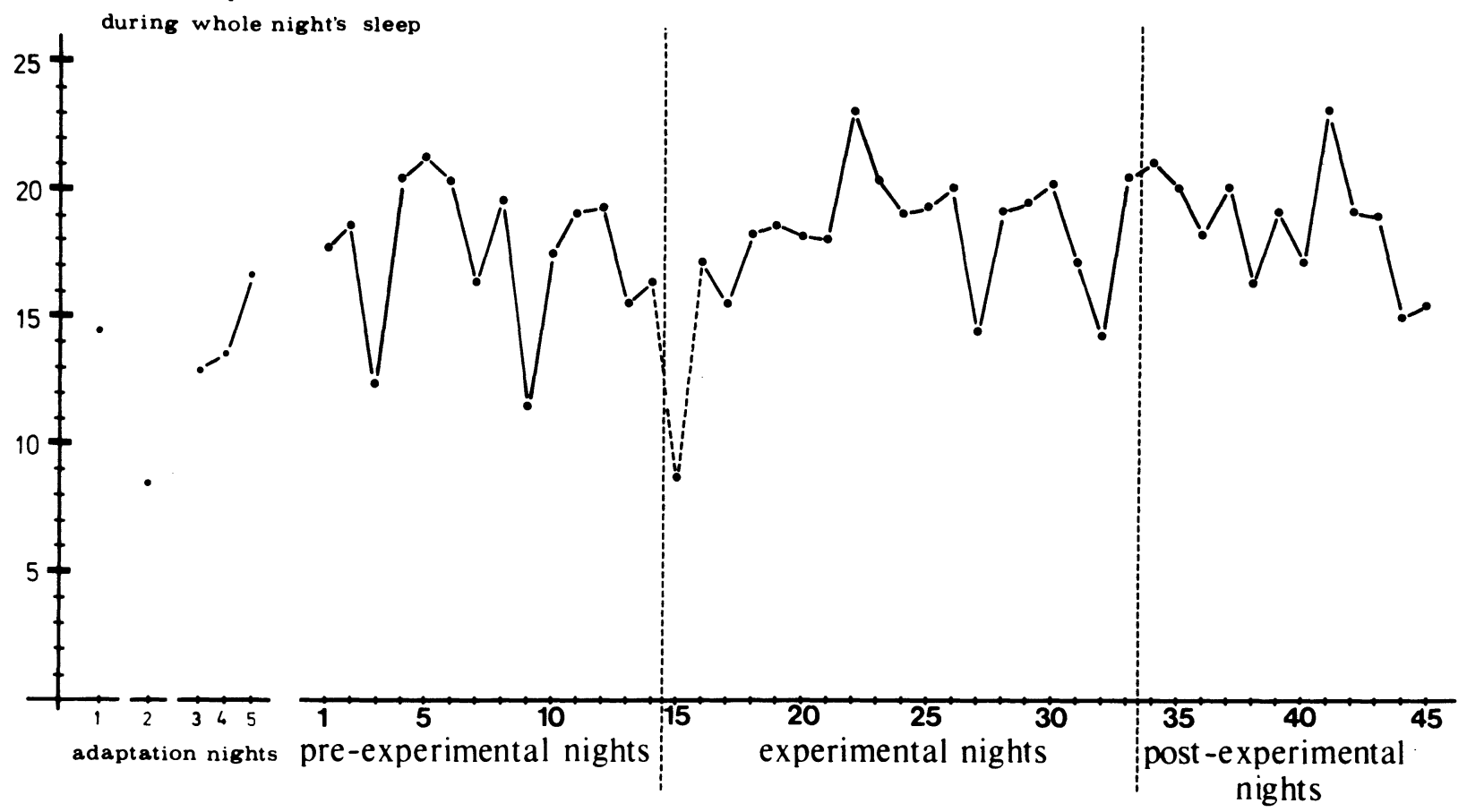

Figure 1. Percentage REM sleep during each night's sleep over the course of the experiment.

mental phase. Both baseline values and any changes in the sleep parameters which may occur under experimental conditions can be more reliably determined.

The tonic aspect of REM sleep, the analysis of which was completed first, showed no relevant significant change under the learning conditions (Figure 1 and Table 2) although these determined practically the entire daily routine with extraordinary intensity for 3 weeks, without the subject's coming under emotional stress or the learning motivation's being reduced. During the language course, the latency of all REM-sleep phases during each night was, on the average, slightly less than during the baseline phases. But only the latency of the third REM-sleep phase was reduced significantly $(p<.05)$. During the learning phase, it was, on the average, 31 min shorter compared to the preexperimental baseline phase and, on average, 23 min shorter compared to the postexperimental baseline phase. In all, this effect was too weak to lead to a clear shortening of the NREM-REM-period duration, and thereby to an increase of REM sleep. The tendency toward a shorter REM-sleep latency is mentioned here, because of a remarkable, similar result in animal experiments. There it was shown, with a high degree of agreement between numerous experiments, that a significant increase in REM-sleep duration occurs after successful learning. This did not occur, however, due to an increase in the duration of the individual REM-sleep phases, but because the number of REM-sleep phases increased (e.g., Fishbein, Kastaniotis, \& Chattman, 1974; Leconte, Hennevin, \& Bloch, 1973). With the same average duration of REM-sleep phases, the ultradian REM-sleep rhythm must have been shortened in order for an increase in REM sleep to occur after learning. It seems that, by learning, pressure is exerted on the trigger mechanism of REM sleep in rats and mice. In the sense of the hypothesis as to memory function of REM sleep, one could assume that in animals an increased requirement for REM sleep exists for the processing and consolidation of newly attained experiences.

From the results of the present study, one can only conclude that intensive learning by the subject did not influence his REM sleep in its tonic aspects. However, it cannot be concluded that no specific activity for processing and storing of new information takes place during REM sleep. It is quite possible that for humans the REM-sleep duration occurring in normal sleep is sufficient to handle the memory processes specific to REM sleep even with an unusually high input of new information. If this is true, then retention must be impaired by REMD. This was not the case in the few experiments which have been conducted, so that up to the present there is no experimental confirmation for a memory-promoting 
Table 2

Means and Standard Deviations of REM Sleep Variables for the Preexperimental, Experimental, and Postexperimental Nights

\begin{tabular}{|c|c|c|c|c|c|c|}
\hline \multicolumn{3}{|l|}{ Sleep Parameters } & $\begin{array}{l}\text { Preexperimental } \\
\text { Baseline Nights } \\
n=14\end{array}$ & $\begin{array}{c}\text { Experimental } \\
\text { Nights } \\
n=18\end{array}$ & $\begin{array}{l}\text { Postexperimental } \\
\text { Baseline Nights } \\
n=12\end{array}$ & $\begin{array}{c}\text { Kruskal-Wallis } \\
\text { Test Statistics } \\
\text { (H) }\end{array}$ \\
\hline \multicolumn{2}{|l|}{$\begin{array}{l}\text { Sleep period time* } \\
\text { (SPT), (min) }\end{array}$} & $\begin{array}{l}\text { mean } \\
\mathrm{SD}\end{array}$ & $\begin{array}{r}447.89 \\
19.67\end{array}$ & $\begin{array}{r}451,28 \\
20,87\end{array}$ & $\begin{array}{r}458.71 \\
20.34\end{array}$ & \\
\hline \multicolumn{2}{|l|}{ \%REM sleep/SPT } & $\begin{array}{l}\text { mean } \\
\text { SD }\end{array}$ & $\begin{array}{r}17.72 \\
2.87\end{array}$ & $\begin{array}{r}18.66 \\
2.20\end{array}$ & $\begin{array}{r}18.93 \\
2.45\end{array}$ & 0.73 \\
\hline \multirow[t]{4}{*}{$\begin{array}{l}\text { of REM phase } \\
\text { (min) }\end{array}$} & ** & $\begin{array}{l}\text { mean } \\
\text { SD }\end{array}$ & $\begin{array}{l}72.36 \\
13.53\end{array}$ & $\begin{array}{r}70.08 \\
8.15\end{array}$ & $\begin{array}{l}75.04 \\
11,43\end{array}$ & 0.78 \\
\hline & 2 & $\begin{array}{l}\text { mean } \\
\mathrm{SD}\end{array}$ & $\begin{array}{r}178.36 \\
28.04\end{array}$ & $\begin{array}{r}168.97 \\
18.92\end{array}$ & $\begin{array}{r}175.17 \\
24.92\end{array}$ & 0.21 \\
\hline & 3 & $\begin{array}{l}\text { mean } \\
\text { SD }\end{array}$ & $\begin{array}{r}298.75 \\
48.34\end{array}$ & $\begin{array}{r}267.36 \\
22.46\end{array}$ & $\begin{array}{r}290.75 \\
24.17\end{array}$ & $\begin{aligned} 6.28 & \text { sign } \\
& p<.05\end{aligned}$ \\
\hline & 4 & $\begin{array}{l}\text { mean } \\
\text { SD }\end{array}$ & $\begin{array}{r}376.54 \\
39.98\end{array}$ & $\begin{array}{r}371.42 \\
31.51\end{array}$ & $\begin{array}{r}385.36 \\
24.03\end{array}$ & 1.58 \\
\hline \multirow[t]{3}{*}{$\begin{array}{l}\text { Duration (min) of } \\
\text { REM sleep phase } \dagger\end{array}$} & 1 & $\begin{array}{l}\text { mean } \\
\text { SD }\end{array}$ & $\begin{array}{r}16.46 \\
8.23\end{array}$ & $\begin{array}{r}14.58 \\
5.83\end{array}$ & $\begin{array}{l}18.04 \\
10.79\end{array}$ & 0.13 \\
\hline & 2 & $\begin{array}{l}\text { mean } \\
\text { SD }\end{array}$ & $\begin{array}{l}32,89 \\
21,95\end{array}$ & $\begin{array}{l}27.95 \\
14,61\end{array}$ & $\begin{array}{l}32.83 \\
11.65\end{array}$ & 0.79 \\
\hline & 3 & $\begin{array}{l}\text { mean } \\
\text { SD }\end{array}$ & $\begin{array}{l}27,54 \\
11.40\end{array}$ & $\begin{array}{l}36.13 \\
17.05\end{array}$ & $\begin{array}{l}38,96 \\
18.92\end{array}$ & 3.77 \\
\hline \multirow[t]{3}{*}{$\begin{array}{l}\text { REM sleep phase } \\
\text { (min) }\end{array}$} & in & $\begin{array}{l}\text { mean } \\
\text { SD }\end{array}$ & $\begin{array}{r}11.68 \\
6.66\end{array}$ & $\begin{array}{l}8.92 \\
6.07\end{array}$ & $\begin{array}{r}11.38 \\
7.96\end{array}$ & 1.49 \\
\hline & 2 & $\begin{array}{l}\text { mean } \\
\text { SD }\end{array}$ & $\begin{array}{l}22.79 \\
15.82\end{array}$ & $\begin{array}{r}19.77 \\
9.89\end{array}$ & $\begin{array}{r}21.21 \\
7.83\end{array}$ & 0.15 \\
\hline & 3 & $\begin{array}{l}\text { mean } \\
\text { SD }\end{array}$ & $\begin{array}{l}21.29 \\
10.98\end{array}$ & $\begin{array}{l}23.03 \\
10.56\end{array}$ & $\begin{array}{l}26.54 \\
13.01\end{array}$ & 1.95 \\
\hline \multirow[t]{3}{*}{ (min) phase } & $\begin{array}{c}\text { cycle } \\
1\end{array}$ & $\begin{array}{l}\text { mean } \\
\text { SD }\end{array}$ & $\begin{array}{l}88.50 \\
17,87\end{array}$ & $\begin{array}{l}84.92 \\
11,23\end{array}$ & $\begin{array}{l}81.67 \\
24.28\end{array}$ & 0.27 \\
\hline & 2 & $\begin{array}{l}\text { mean } \\
\text { SD }\end{array}$ & $\begin{array}{r}123,14 \\
26.35\end{array}$ & $\begin{array}{r}115,39 \\
27.33\end{array}$ & $\begin{array}{r}119,54 \\
18.16\end{array}$ & 0.37 \\
\hline & 3 & $\begin{array}{l}\text { mean } \\
\text { SD }\end{array}$ & $\begin{array}{r}113.68 \\
36.45\end{array}$ & $\begin{array}{r}112.25 \\
20.18\end{array}$ & $\begin{array}{r}120.17 \\
25.32\end{array}$ & 1.43 \\
\hline \multirow[t]{2}{*}{$\begin{array}{l}\text { No. of REM sleep : } \\
\text { phases per night }\end{array}$} & $a+t$ & $\begin{array}{l}\text { mean } \\
\text { SD }\end{array}$ & $\begin{array}{l}4.21 \\
0.58\end{array}$ & $\begin{array}{l}4.17 \\
0.38\end{array}$ & $\begin{array}{l}4.08 \\
0.51\end{array}$ & \\
\hline & $\mathrm{b}+\dagger$ & $\begin{array}{l}\text { mean } \\
\text { SD }\end{array}$ & $\begin{array}{l}3.64 \\
0.74\end{array}$ & $\begin{array}{l}3,56 \\
0.62\end{array}$ & $\begin{array}{l}3.67 \\
0.49\end{array}$ & \\
\hline
\end{tabular}

*SPT = time from sleep onset until awakening in the morning

**time from sleep onset (appearance of the first sleep spindle) until the onset of the REM sleep phases

tincluding all sleep stages 1 and 2 and movement time during a REM phase

t the last REM phases of the nights during which awakening occurred or which were not followed by more than 15 min of NREM sleep are (a) included (b) not included.

effect of REM sleep for cognitive learning processes in humans.

The often reported positive effect of sleep on retention of verbal material which is learned before falling asleep, must therefore be related to NREM sleep. This is indicated by results of experiments with humans which investigated the influence of the first and second halves of a night's sleep on the retention of verbal learning material. The first half of a night's sleep, in which the NREM sleep far exceeds REM sleep, had a more favorable effect on retention than did the second half of the night's sleep, during which a considerably greater proportion of REM sleep is to be observed (Barrett \& Ekstrand, 1972; Fowler, Sullivan, \& Ekstrand, 1973; Yaroush, Sullivan, \& Ekstrand, 1971).

Greenberg (1970) proposed the hypothesis that in REM sleep only experiences which are emotionally meaningful to the subjects are processed and that in the NREM sleep the consolidation of purely cogni- 
tive learning material is promoted. In the meantime, results of more recent experiments with humans tend to support this hypothesis (Cartwright, Lloyd, Butters, Weiner, McCarty, \& Hancock, 1975; Grieser, Greenberg, \& Harrison, 1972).

In the present, ongoing study, the scoring of the NREM sleep stages and the evaluation of the phasic components of various biosignals, as well as some special computer analyses of the EEG, are to be completed. The above-mentioned reduction in sleep stage 4 during the learning phase does possibly indicate that some relationship may exist between slow-wave sleep and intensive cognitive learning.

\section{REFERENCE NOTE}

1. Rechtschaffen, A., \& Kales, A. (Eds.). A manual of standardized terminology, techniques and scoring system for sleep stages of human subjects. Bethesda, Md: National Institute of Health Publication No. 204, 1968.

\section{REFERENCES}

Adelmann, S., \& Hartmann, E. Psychological effects of amitriptyline-induced dream-deprivation. Psychophysiology, 1968, 5, 240.

Agnew, H., Webb, W., \& Williams, R. The first night effect. Psychophysiology, 1966, 2, 263-266.

Allen, S. R., Oswald, I., Lewis, S., \& Tagney, J. The effect of distorted visual input on sleep. Psychophysiology, 1972, 9. 498-504.

AsERINSKY, E., \& KLEITMAN, N. Regularly occurring periods of eye motility. and concomitant phenomena during sleep. Science, 1953. 118. 273-274.

Barrett, T. R., \& Ekstrand, B. R. Effect of sleep on memory: III. Controlling for time-of-day effects. Journal of Experimental Psychology, 1972, 96, 321-327.

Benson, K., \& Feinberg, I. Sleep and memory: Retention 8 and 24 hours after initial learning. Psychophysiology, 1975, 12, 192-195.

Berger, R. J. The sleep and dream cycle. In A. Kales (Ed.), SleepPhysiology and pathology. A Symposium. Philadelphia: Lippincott, 1969. Pp. 17-32.

BREger. L. Functions of dreams. Journal of Abnormal Psychology, 1967, 72, 1-28.

Cartwright, R. D., Lloyd, S., Butters, E., Weiner, L., MCCARTHY, L., \& HANCOCK, J. Effects of REM time on what is recalled. Psychophysiology, 1975, 12, 561-568.

Castaldo, V., KrYNicki, V., \& Goldstein, J. Sleep stages and verbal memory. Perceptual and Motor Skills, 1974, 39. 1023-1030.

CHERnik, D. A. Effect of REM sleep deprivation on learning and recall by humans. Perceptual and Motor Skills, 1972, 34, 283-294.

Chernik, D. A., Schless, A., \& Mendels, J. Reliability of sleep measures. Sleep Research, 1975, 4, 157.

Clausen, J., Sersen, E. A., \& Lidsky, A. Variability of sleep measures in normal subjects. Psychophysiology, 1974, 11, 509-516.

De Koninck, J., Proulx, G., Healy, T., Arsenault, R., \& PrÉvost, F. Intensive language learning and REM sleep. Sleep Research, 1975, 4, 150.

Dement, W.. \& Kleitman, W. Cyclic variations in EEG during sleep and their relation to eye movements, body motility and dreaming. EEG and Clinical Neurophysiology, 1957, 9, 673-690.

DEwAN, E. M. The $P$ (programming) hypothesis for REMs. Psychophysiology, 1968, 4, 365-366.
DEwAN, E. M. The programming (P) hypothesis for REM sleep. In E. Hartmann (Ed.), Sleep and dreaming (International Psychiatric Clinics, Vol. 7). Boston: Little, Brown, 1970. Pp. 295-307.

Ekstrand, B. R., Sullivan, M. J., Parker, D. F., \& West, J. N. Spontaneous recovery and sleep. Journal of Experimental Psychology, 1971, 88, 142-144.

Empson, J. A., \& Clarke, P. R. Rapid eye movement sleep and remembering. Nature (London), 1970, 227, 287-288.

FeINBERG, I. Across-night changes in the EEG characteristics of human sleep. Sleep Research, 1975, 4, 158.

Feldman, R. E., \& Dement, W. C. Possible relationships between REM sleep and memory consolidation. Psychophysiology, 1968, 5. 243.

Fishbein, W. Interference with conversion of memory from shortterm to long-term memory by partial sleep deprivation. Communications in Behavioral Biology (A), 1970, 5, 171-175.

Fishbein, W. Disruptive effects of rapid eye movement sleep deprivation on long-term memory. Physiology and Behavior, 1971, 6. 279-282.

Fishbein, W., Kastaniotis, C., \& Chattman, D. Paradoxical sleep: Prolonged augmentation following learning. Brain $R e$ search, 1974, 79, 61-75.

Fowler, M. J., Sullivan, M. J., \& Ekstrand, B. R. Sleep and memory. Science, 1973, 179, 302-304.

GaARDNER, K. A conceptual model of sleep. Archives of General Psychology, 1966, 14, 253-260.

GLobus, G. G. Quantification of the REM sleep cycle as a rhythm. Psychophysiology, 1970. 7, 248-253.

GREenberg, R. Dreaming and memory. In E. Hartmann (Ed.), Sleep and dreaming (International Psychiatric Clinics, Vol. 7 ). Boston: Little, Brown, 1970. Pp. 258-267.

Greenberg, R., Pearlman, C., Fingar, R., Kantrowitz, J., \& KAWLICHE, S. The effects of dream deprivation-Implications for a theory of the psychological function of dreaming. British Journal of Medical Psychology, 1970, 43, 1-11.

Grieser, C., Greenberg, R., \& Harrison, R. H. The adaptive function of sleep: The differential effects of sleep and dreaming on recall. Journal of Abnormal Psychology, 1972, 80, 280-286.

Grosser, G. S., \& Siegal, A. W. Emergence of a tonic-phasic model for sleep and dreaming: Behavioral and physiological observations. Psychological Bulletin, 1971, 75, 60-72.

Hartmann, E. The 90-minute sleep-dream cycle. Archives of General Psychiatry, 1968, 18, 280-286.

HAURI, P. Effects of evening activity on early night sleep. Psychophysiology, 1968, 4, 267-277.

Hennevin, E., Leconte, P., \& Bloch, V. Augmentation du sommeil paradoxal provoquee par l'acquisition, l'extinction et la réacquisition d'un apprentissage à renforcement positif. Brain Research, 1974, 70, 43-54.

HERNÁNDEZ-PÉon, R. A neurophysiological model of dreams and hallucinations. Journal of Nervous and Mental Disease, 1966. 141, 623-650.

HernÁNDEZ-PEón, R. Neurophysiology, phylogeny and functional significance of dreaming. Experimental Neurology, 1967, Supplement 4, 106-141.

Hockey, G. R., Davies, S., \& Gray, M. M. Forgetting as a function of sleep at different times of day. Quarterly Journal of Experimental Psychology, 1972, 24, 386-393.

Holdstock, T. L., \& Verschoor, G. J. Student sleep patterns before, during and after an examination period. South African Journal of Psychology, 1974, 4, 16-24.

Jenkins, J. G., \& Dallenbach, K. M. Obliviscence during sleep and waking. American Journal of Psychology, 1924, 35, 605-612.

Jouvet, M. The rhombencephalic phase-of sleep. Progress in Brain Research, 1963, 1, 406-424.

Jouvet, M. Etude de la dualité des états de sommeil et des mécanismes de la phase paradoxale. In M. Jouvet (Ed.), Aspects anatomo-fonctionnels de la physiologie du sommeil. (Colloque internationaux du centre national de la recherche scientifique, No. 127, Lyon, 1963). Paris: Centre National de la Recherche Scientifique, 1965. Pp. 397-450. (a) 
Jouvet, M. Paradoxical sleep-A study of its nature and mechanisms. Progress in Brain Research, 1965, 18, 20-62. (b)

Leconte, P., \& Hennevin, E. Characteristiques temporelles de l'augmentation de sommeil paradoxal consecutiv á l'apprentissage chez le rat. Physiology and Behavior, 1973, 11, 677-687.

Leconte, P., Hennevin, E., \& Bloch, V. Analyse des effets d'un apprentissage et de son niveau d'acquisition sur le sommeil parad oxal consecutif. Brain Research, 1973, 49, 367-379.

Levy. C. M.. \& Coolidge, F. L. Empson and Clarke re-examined. Sleep Research, 1975. 4. 151.

LEWIS, S. A. The paradoxical sleep cycle revisited. In L E. Scheving. E. Halberg, \& J. E. Pauly (Eds.), Chronobiology. Tokyo: Igaku Shoin, 1974. Pp. 487-490.

Linden, E. R., Bern, D., \& Fishbein, W. Retrograde amnesia: Prolonging the fixation phase of memory consolidation by paradoxical sleep deprivation. Physiology and Behavior, 1975. 14. 409-412.

Lovatt, D. J..\& WARR, P. B. Recall after sleep. American Journal of Psychology, 1968, 81, 253-257.

MEISSNER, W. W. Hippocampal functions and learning. Journal of Psychiatric Research, 1966, 4, 235-304.

Meissner, W. W. Dreaming as process: I. The dreaming state. II. Metapsychological considerations. International Journal of Psycho-Analysis, 1968, 49, 63-79.

Molinari, S., Foulkes, D. Tonic and phasic events during sleep: Psychological correlates and implications. Perceptual and Motor Skills, 1969, 29, 343-368.

Moruzzi, G. General discussion. In M. Jouvet (Ed.), Aspects anatomo-fonctionnels de la physiologie du sommeil (Colloque internationaux du centre national de la recherche scientifique, No. 127. Lyon, 1963). Paris: Centre National de la Recherche Scientifique, 1965. Pp. 638-640.

Moruzzi, G. The functional significance of sleep with particular regard to the brain mechanisms underlying consciousness. In J. C. Eccles (Ed.), Brain and conscious experience. Berlin, Heidelberg, \& New York: Springer Verlag, 1966. Pp. 345-388.

Moses, J., Lubin, A., Naitoh, P., \& Johnson, L. C. Reliability of sleep measures. Psychophysiology, 1972, 9, 78-82.

Muzio, J. N., Roffwarg, H. P., Anders, C. B., \& Muzio, L. G. Retention of rote-learned meaningful verbal material and alterations in the normal sleep EEG pattern. Psychophysiology, 1972, 9. 108.

Newman, E. A., \& Evans, C. R. Human dream processes as analogous to computer programme clearance. Nature (London), 1965. 206. 534.

Oswald, J. Human brain protein, drugs and dreams. Nature (London), 1969, 223, 893-897.
Pearlman, C. A., JR., \& Becker, M. Brief posttrial REM sleep deprivation impairs discrimination learning in rats. Physiological Psychology, 1973, 1, 373-376.

Pearlman, C. A., JR., \& Becker, M. REM sleep deprivation impairs barpress acquisition in rats. Physiology and Behavior, 1974, 13, 813-817. (a)

Pearlman, C. A., JR., \& Becker, M. REM sleep deprivation impairs serial reversal and probability maximizing in rats. Physiological Psychology, 1974, 2, 509-512. (b)

Prévost, F., De Koninck, J., \& Proulx, G. Stage ReM rapid eye movements following visual inversion: Further investigation and replication. Sleep Research, 1975, 4, 57.

Rechtschaffen, A., \& Verdone, P. Amount of dreaming: Effect of incentive, adaptation to laboratory, and individual differences. Perceptual and Motor Skills, 1964, 19, 947-958.

ShaPIRo, A. Dreaming and physiology of sleep. A critical review of some empirical data and a proposal for a theoretical model of sleep and dreaming. Experimental Neurology, 1967, Supplement $4,56-8 \mathrm{r}$.

Schmidt, H. S., \& Kaelbling, R. The differential laboratory adaptation of sleep parameters. Biological Psychiatry, 1971, 3. 33-45.

Smith, C. F.. Kitahama, K., Valatx, J. L., \& Jouvet, M. Increased paradoxical sleep in mice during acquisition of a shock avoidance task. Brain Research, 1974, 77, 221-230.

SNYDER, F. Sleep and dreaming: Progress in the new biology of dreaming. American Journal of Psychiatry, 1965, 122, 377-391.

STERN, W. C. Acquisition impairments following rapid eye movement sleep deprivation in rats. Physiology and Behavior, 1971, 7 . 345-352.

Webb, W. G., \& Agnew, H. W. Measurement and characteristics of nocturnal sleep. In L. E. Abt \& B. Reiss (Eds.), Progress in clinical psychology (Vol. 8) Dreams and dreaming. New York: Grune \& Stratton, 1969. Pp. 2-27.

Wolfowitz, B. E., \& Holdstock, T. L. Paradoxical sleep deprivation and memory in rats. Communications in Behavioral Biology, 1971, 6, 281-284.

Yaroush, R., Sullivan, M. J., \& Ekstrand, B. R. Effect of sleep on memory: II. Differential effect of the first and second half of the night. Journal of Experimental Psychology, 1971, 88. 361-360.

Zimmerman, J., Stoyva, J.. \& Metcalf, D. Distorted visual feedback and augmented REM sleep. Psychophysiology, 1970, 7. 298.

(Received for publication October 20, 1976; revision accepted February 23, 1977.) 